\title{
THE WORLD OF LOFTY FEELINGS AND GOOD MANNERS, OR NORWID'S LAW OF INVERSION
}

\section{THE SECRET IN THE WORD}

Norwid's life and work have been studied for over a hundred years, which led to the amassing of an immense body of well-documented and thus scientifically reliable knowledge that is now difficult to enlarge upon. However, there are still areas that call for speculation, yielding so far only tentative results, although in the case of texts like Tajemnica lorda Singelworth [Lord Singleworth Secret] this seems justified, not only because its title contains the word "secret," which cannot be ignored in light of Norwid's anthropology, but also due to the fact that the Parisian context constitutes in this case something more than just a historical setting - a lively background of biography and opinion. The dirty Paris of the ragpickers ${ }^{2}$ is, after all, the city where Norwid lived, and despite the fact that Tajemnica... is set in Venice the text could be read alongside Benjamin's "The Paris of the Second Empire in Baudelaire" (just like Poe's "The Mystery of Marie Rogêt," which is set in Paris but actually takes place in New York). The very character of the Lord, who is a decadent, provocative, and artistically-minded philosopher of taste, as well as the landscape, where palimpsests of trash heaps play important role, constitute only some of the clues that evoke associations with Paris. However, the secret also has a literal dimension - one that does not concern only the mysteri-

${ }^{1}$ Cf. M. AdAmiec, 'Tajemnica lorda Singelworth' albo metafizyka balonu, "Studia Norwidiana” 3-4: 1985-1986, p. 202.

${ }^{2}$ Cf. W. Benjamin, "The Paris of the Second Empire in Baudelaire," [in:] IDEm, The Writer of Modern Life: Essays on Charles Baudelaire, Cambridge, Mass. 2006, p. 54ff.

${ }^{3}$ For a discussion of what Norwid might have needed Venice for, see: K. TRYBUŚ, Stary poeta. Studia o Norwidzie, Poznań 2000, p. 188ff. 
ous name, nickname, or neologism, but also a lexical or cultural association that escapes our attention, remaining a mere possibility. Two small discoveries open the following consideration of Tajemnica lorda Singelworth.

The first one concerns the second stanza of the poem "Po balu" [After the Ball] from the fantasy Za kulisami [Backstage], which offers a description of a waxed floor, where "tańcowało-było wiele mask" [where many masks had danced"] (PWsz I, 318). The waltzing pairs left circles of shoe marks in a deserted room. Interpreters of this passage are puzzled by the character of this surface: "na jasnej woskiem zwierzchni szyb" [on the wax-brightened coating]. The parquet (since marble is never waxed) is not usually associated with glass. This seems to be explained in the preceding stanza, which describes a contemplation of daybreak from a window. The lyrical subject stands at the window (to be opened soon) and - we may assume - notes that it reflects the floor behind him. At the same time, as we know from experience, the speaker discerns outlines of nearby roofs in the first rays of the rising sun. Thus, the windowpane appears "semi-permeable:" the two images overlap, as suggested in the text. It is not the case that the observer stands in the middle of the room and then moves to the window, but rather stands there right from the start. Still, this situation constitutes only the basis for the second couplet in the second stanza. As it turns out, something can be glimpsed on the scratched floor, although the poet does not reveal what it is. Why would he deny us this knowledge? It can be argued, however, that Norwid actually tells us what he saw: "Czarodziejskich jakoby pisań tryb / Z ziemi do mnie mówił, jak z księgi" [The script spoke to me from the floor / As if in magical writings, a sacred book] (PWsz I, 318). What we encounter here are circles and dances, magic and earth. It becomes necessary to recall at this stage the so-called witches' circles, which can be found in forest clearings, formed by circles of mushrooms. Folklore, also in the Polish tradition, associates them with witches dancing during the night of the sabbath. In the light, the unfortunate masked ball at Hôtel Lambert, which was not cancelled despite the recent death of Zygmunt Krasiński, is negatively assessed, the floor tells us, as a clear manifestation of impure forces, a true witches' sabbath. However, since it is difficult to ascertain that Norwid knew the folk tradition of magical rituals, this interpretation must remain optional, even though it seems speculatively more convincing than many other readings.

The second example is more brief. In the poem Sfinks [I] [Sphinx], a certain prophecy materializes, as indicated by Archimedes rising from the dead. Soon, the tombstone on his imagined grave will move: "gwinty jego śrub / Sklepień czarnych opowiada trzask" [its screw-threads / tell the crash of the black vaults]

${ }^{4}$ Citations from "After the Ball" come from: C. NorwiD, Poems, translated from the Polish by D. Borchardt in collaboration with A. Brajerska-Mazur, p. 125. 
(PWsz I, 329). This unusual vision will not lose any of its magic and may even become easier to understand if we recall that, oddly enough, the French word "cric" means both "crack" and "lever." The latter was the tool that the Greek thinker meant to use in order to move the earth, making it his emblem, just like the bathtub. Norwid could mistakenly regard the Archimedean screw ${ }^{5}$ to be a kind of lever or jack. In other words, this poetic image may have been shaped by terms drawn from the language he used on a daily basis. However, since his ignorance in this matter cannot be proven, this hypothesis must remain inconclusive.

The above two short speculations are not thematically linked to Tajemnica... but set the tone for the interpretation that follows, which adds a certain context that can but does not have to guide the reading of a specific episode from this work. As a citizen of the literary world, a proto-modernist, and an eccentric worthy of other late-nineteenth-century rebels, Norwid demands a defiant reading that would acknowledge his irony, bitterness, and humour.

In the introduction to Trylogia wloska [Italian Trilogy], Juliusz Wiktor Gomulicki writes:

Norwid, who remembered Swift and knew The Intestine of Leviathan by Victor Hugo and The Odors of Paris by Louis Veuillot, which were published earlier, could turn to subjects he saw fitting to express utter contempt for nineteenth-century European civilization, especially for his own society, which kept trampling on him, treading him into "trash" and "mud." It is from this society that the daydreamer Singelworth and Norwid himself would flee [... ${ }^{6}$

The suggestion of a biographical pact between Norwid and Lord Singelworth seems to be tied by Gomulicki to a philosophy of uncleanliness, which appears more interesting than the existential category of an outcast. One also needs to keep in mind that canals (not the Venetian ones though) and palimpsests of historic-civilizational refuse constitute an important theme and image in texts written at that time by none other than Bolesław Prus. ${ }^{7}$ Still, in Norwid's case the theme of (un)cleanliness is closely connected with the philosophy of person. This has two grounds. First, if we acknowledge the human being as a whole, we need to accept the whole package, not just the fresh and fragrant aspects. Second, the theme of (un)cleanliness carries the rebellious potential to undermine our habits and revalue our hierarchies. What is unclean does not have to be dirty, and vice versa. As an

${ }^{5}$ Certainly, the word "gwinty" [screw threads] makes it possible to read the text in native terms.

6 J.W. Gomulicki, O ,,Trylogii włoskiej” Norwida. Geneza - ksztaltowanie - wymowa, [in:] C. NorwID, Trylogia włoska, ed. J.W. Gomulicki, Warszawa 1979, pp. 44-45.

7 E.g. Pod szychtami or Ogród Saski. Cf. B. Prus, Pisma wszystkie. Humoreski, nowele, opowiadania, vol. 2, ed. T. Żabski, Warszawa-Lublin 2015, pp. 113-127. 
inhabitant of Paris, an observer and an ironist, Norwid, who would draw on the morally ambiguous biographies of figures like Lord Byron, discovers the world from the angle of the cesspool, discerning in it not only Christian dignity but also a fascinating yet disturbing domain. Uncleanliness thus facilitates the kind of play with meaning that locates reflection on humankind within a perverse, upside-down morality play strongly marked by irony.

\section{INVERSION}

Norwid's poetic sensibility brings order to his universe in accordance with certain evident principles discussed at length in studies of his works. Norwid's law of inversion is a semiotic rule which says that the great can be discerned in the small, the eternal in the fleeting, the high in the low, the loud in the silent - in short: the meaningful in the meaningless. Therefore, nothing is at it seems, and nothing is truly banal. This choice of perspective makes him an ironist and reveals in his writings the impulse to seek meaning. ${ }^{8}$ After all, extremes not only come into contact but also expose each other. This certainly does not happen every time, but basically whenever we are presented with lofty emotions and good manners, i.e. when inauthenticity prevails.

Thus, it is possible to formulate the thesis that this law of inversion manifests most clearly in the Italian trilogy of the 1880s, especially in Tajemnica.... The story of this prose piece focuses, as is usually noted, on the aforementioned search for meaning, but its ironic dimension is less often acknowledged. ${ }^{9}$ However, since lofty emotions and good manners reach unprecedented heights in this work, the law of inversion demands that we trace in it extremes that would compromise this refinement.

In 1887 Oscar Wilde published the short story Lord Arthur Savile's Crime: A Study of Duty in the magazine "The Court and Society Review" (the piece was later released in book form in 1891). Lady Windermere - one of the protagonists, who embodies lofty emotions and good manners - offers the following summary of a palmist's prophecy:

${ }^{8}$ The attitude of an ironist in the context of the work's communicative framework is discussed in relation to Tajemnica ... by Sławomir Rzepczyński in: O umyśle 'zgadobliwym'. 'Tajemnica lorda Singelworth', "Studia Norwidiana" 14: 1996, p. $105 \mathrm{ff}$.

${ }^{9}$ Naturally, the question of irony has not been entirely disregarded in interpretations. Among recent publications it is worth to quote the article by Ewangelina Skalińska, Jeszcze o 'Tajemnicy lorda Singelworth'. Między ironia a autoironia, "Colloquia Litteraria" 2017, no. 1, pp. 107-122. 
Next year, for instance, I shall be in great danger, both on land and sea, so I am going to live in a balloon, and draw up my dinner in a basket every evening. It is all written down on my little finger, or on the palm of my hand, I forget which. ${ }^{10}$

This concept immediately brings to mind some of the less obvious practices of Norwid's Lord. Nevertheless, it is clearly a concept, confirming the widespread opinion that British aristocrats are capable of anything as far as bizarre behaviour is concerned. In the epoch's collective imagination, a British Lord would be regarded as an eccentric who is both comical and incomprehensible. This is the image conveyed in Offenbach's Parisian Life, imagined by Parisian members of the snobbish Jockey Club, and presented by Jules Verne in his 1872 novel Around the World in Eighty Days, whose inscrutable protagonist Phileas Fogg, Esq. can be deemed a symbol of pushing ahead and upward, just like the incomparable Lord Singelworth.

It needs to be emphasised that both Lord Singelworth and his mysterious rituals are actually a literary cliché that belongs with the popular imagination. By introducing a folk improviser who publicly discusses his secrets, Norwid makes it clear that the Lord shall become another urban legend in Venice, just like the prisoners of Piombi or suicides jumping from the campaniles of San Marco. This idea is also suggested by the story's ending. It serves the legend well not to strip the Lord's actions of a mysterious aura. ${ }^{11}$ Still, Norwid goes to great lengths to preclude any explanations save one. Thanks to the inquisitiveness of the Tsarist secret police, Venetian gossips know that the balloon's basket does not contain any dangerous items, only "etruską okrągłą wazę albo porcelanową" [Etruscan round vase or porcelain] (DW VII, 221). Owing to the indiscretion of the improviser Tony di Bona Grazia, inquisitive onlookers also know that a piece of paper fell from the gondola onto the Murano Island, which does not have written content yet is palimpsestic and can be certainly felt by anyone with a nose. The Lord himself would explain himself by making oblique allusions to digestion, the sham nature of urban hygiene, and Xanthippe, who emptied a chamber pot on the head of Socrates. ${ }^{12}$

\section{BAUDELAIRE'S FRIEND}

As the story informs us, Lord Singelworth would perform his daily rituals in Cairo, Constantinople, Moscow, Vienna, Paris, and Odessa; in short - everywhere.

${ }^{10}$ O. WiLDE, Lord Arthur Savile's Crime and Other Stories, London 1913. Online: https:// www.gutenberg.org/files/773/773-h/773-h.htm (accessed 19 January 2021).

${ }^{11}$ Cf. S. RZEPCZYŃSKI, O umyśle 'zgadobliwym', p. 105.

${ }^{12}$ More precisely: "urnę pełną domowych nieczystości” [an urnful of household refuse] (DW VII, 231). 
As one can surmise, Venice became the setting due to the ambiguity of its sewage system. As is known, this question remains problematic to this day. The abovementioned theme nevertheless brings stronger associations with Paris and does not concern the British aristocrat (who acts as camouflage, just like Venice) but a real person who became a true Parisian urban legend.

The man, a Parisian writer famous for numerous scandals and the complete opposite of Lord Singelworth in terms of views on cleanliness, was named Philoxène Boyer (1827-1867). His life is discussed by Sylvain-Christian David, a scholar of Lautréamont, in the biography titled Philoxène Boyer: Un sale ami de Baudelaire 13 and published in 1987. The book states that "Baudelaire's dirty friend" was the son of an exceptional classical philologist who also had an unusual name: Austremoine. When he was nineteen, it took him only nine months (less than Baudelaire needed) to blow the eighty-thousand-franc inheritance from his father. He then lived in poverty, harassing his friends - Baudelaire, Arsène Houssaye, Théodore de Banville, Flaubert, Gautier, Barbey d'Aurevilly, Villiers de l'Isle Adam, and many other minor figures - with his literary plans, which never materialized, and an unchecked cult of Victor Hugo. He was able to walk across Paris backwards in front of his interlocutor and recite from memory his entire comedy, as if he were reading it. Still, all he left is a volume of mediocre poems, several worthless vaudevilles, a handful of letters, and an album with friendly notes by some of the best French writers from the period. He was probably the last person who spoke with Nerval before he committed suicide. He died before turning forty, two months after Baudelaire.

The point is that he became famous for cultivating filthiness - not due to poverty but out of ideological reasons. He would never use water, not to mention soap, and his friends would comment with fascination on the gradual darkening of his once white shawl. They would also note that he keeps wearing larger and larger shoes, which he explained by saying that he was not clipping nails on his feet. Humble and timid by nature, he would boast about his untidiness, becoming the precursor of later sloven dandies: Alfred Jarry, Max Jacob or Paul Léataud. He turned legendary after the 1855 adventure in the Thierry Hôtel in Lacépède, where he lived. According to Charles Asselineau, he would avoid the landlord by sneaking into his attic through the kitchen window. However, in order to reach the privy he would have to cross the living room. Even if we disregard his debt to the owner, his shyness prevented him from going there and appearing before ladies. Thus, he began to buy the daily La Patrie - a pro-government paper and therefore the cheapest - using its pages to wrap, as Asselineau put it, "les

${ }^{13}$ Cf. S.-Ch. DAvid, Philoxène Boyer: Un sale ami de Baudelaire, Paris 1987, especially pp. 201-202 and 205. 
bizarres effets de la nature" ${ }^{14}$ and throw such packages from the sixth floor onto the street. After some time, however, he realized that this could expose him, and so he began to store the small, cannonball-like packages in the cupboard. When the landlord finally sent for a debt collector and let him inside when the poet was not in, the latter wished to secure the furniture but the former explained they were his. With nothing left to be done, the debt collector commenced to seal the movables. On his command, the locksmith opened the cupboard and revealed over a hundred of the said balls. The debt collector refused to continue, while the room stank so much that no one wanted to rent it, so Boyer moved back in without paying.

The story, one of those that writers tell each other, must have retained some charm three decades later when it was repeated to a frequent visitor to Paris, Oscar Wilde, who aptly tempered it and included as an allusion in his own story. This leads to the conclusion that news of the Paris writer who was so preoccupied with the products of the digestive system might have reached the ears of Norwid, whose poor living conditions later found their way into the world of lofty emotions and good manners as a concealed theme in one his most derisive short stories. According to Norwid's law of inversion, only this dimension of triviality could balance the deranged idealism of Lord Singelworth, who "zbyt wysoko się podnosi, ażeby dotyczyła go nieczystość" ${ }^{15}$ [rises too high up to be concerned with uncleanliness]. After all, even that which is vile and low can be elevated to the greatest heights: "Co ci się podoba, stamtąd rzuć, a potem o safirowej nocy letniej patrz na spadający aerolit... jakże on jest pięknym!..." ${ }^{" 16}$ [You may drop anything from there and then look at the flying object as it falls in the blue summer night... ${ }^{17}$.

As Norwid suggests, such an unusual tension between extremes runs the risk of becoming pathological, in medical rather moral terms. Lord Singelworth is different not just because he wants to be like that but because he must. ${ }^{18}$ In 1888 , the psychiatrist Alexandre Cullerre (1849-1934) published the treatise Les frontières de la folie (translated just three years later into Polish by doctor Ludwik Wol-

${ }^{14}$ Cf. ibid., p. 205.

15 The actual quotation is: "Jednym słowem: za wysoko ja się podnoszę, ażeby dotyczyła mię nieczystość!..." (DW VII, 231) [I rise too high even to be concerned with uncleanliness] and it comes from O. Scherer-VIRSKI, The Modern Polish Short Story, Hague 1955, p. 61.

${ }^{16}$ DW VII, 231-232.

17 O. SCHERER-VIrSKI, The Modern Polish Short Story, p. 61-62.

${ }^{18}$ For a discussion of inabilities and compulsions see: K. SAMSEL, Norwid-Conrad. Epika w perspektywie modernizmu, Warszawa 2015, p. $199 \mathrm{ff}$. 
berg $\left.{ }^{19}\right)$. The study addresses the question of psychological norm, i.e. what is considered as untypical behaviour. The following is one discussed example:

Mr de Puy..., officer of the Legion of Honour, former military officer, settled in a former church in B... after retiring, where he lived an eccentric and vulgar life. He lived with people of the worst kind, walked the streets in shirt but without underwear or stockings, publicly relieving himself on the balcony in this costume. The family asked the doctors Rousselin and Lunier to study his case. ${ }^{20}$

Conclusions drawn from medical examinations surprised the doctors, but are characteristic for the type of eccentricity analysed by Cullerre: "The lodgings of Mr de Puy... [...] reveal that this man has bizarre customs; he lives in terrible, indescribable filthiness." ${ }^{21}$ Apart from great cunning and education, such eccentricity and lunacy would amaze everyone. Another characteristic feature of this mind was also that he would eagerly strip the poetic appeal from everything, reducing lofty facts to mundane realism and materialism. For example, after enthusiastically praising a certain poetic work, he would conclude his apology with the words: "do not forget, however, that the author of this masterpiece visits the privy every day." 22

One could say that the patient fell victim to an overdeveloped law of inversion. At this point, the medical and the literary dimensions overlap. In 1732 Jonathan Swift published the long poem The Lady's Dressing Room, whose protagonist Strephon sneaks into the boudoir of the godly Celia, whom he adores beyond all measure, and assists her for one hundred and seventeen lines in the toilet. He looks at the sweaty shirts, combs full of dandruff, greasy cloths, grimy towels, handkerchiefs full of snot, jars full of spit, cosmetics made from dog's intestines, and bras smeared with rancid fat. Finally, he makes the worst discovery: "Oh! Celia, Celia, Celia shits!" (line 118). Struck down with inversion, the exacerbated idealism reaches the ground. Luckily, one hundred and fifty years later Lord Singelworth appears to once again elevate it to such heights. This is perhaps the reason why Juliusz Wiktor Gomulicki called Tajemnica... - with characteristic restraint - a Swiftian work. ${ }^{23}$ Was he right?

\footnotetext{
19 A. Cullerre, U wrót obłędu. Studyum psychologiczne, trans. L. Wolberg, Warszawa 1891.

${ }^{20}$ Ibid., p. 122.

${ }^{21}$ Ibid., pp. 123-124.

${ }^{22}$ Ibid., p. 121.

23 J.W. Gomulicki, O 'Trylogii włoskiej’, p. 45.
} 


\section{APPENDIX. UNCLEANLINESS VERSUS SOAP}

Readers of Norwid may recall the poem "Purytanizm" [Puritanism], which contains the following passage:

Słowem - że w mydło wierzę niezachwianie,

Lecz gdyby kto chciał, abym przez to samo

Wziął się do pracy: stawić z nim mieszkanie

Bogów, gościnne tryumfalną bramą,

$\mathrm{Z}$ tak niesłychanie przeczystej materii,

Jak purytanizm, to... zrobiłbym może

Nie kościół, ale - utrapienie Boże,

Alabastrowe jak śniegi w Syberii!

$\left(\right.$ PWsz II, 67-68) ${ }^{24}$

This poem, included in a letter to M. S. (Marian Sokołowski), was written in 1865, perhaps when the author was still under the impression of Hippolyte Taine's History of English Literature (1863), which he read after the drama of the January Uprising ended. The derisive tone of the poem can be regarded as an echo of Taine's famous account of Puritan mentality, which could serve the Frenchman as a secular exorcism of the still lively spirit of Port-Royal. As is easily noticed, Norwid's poem has the structure of a syllogism, with cursive marking the minor premise (Primo) and the conclusion (Ergo), lacking the passed-over major premise (Secundo). However, it is not difficult to find where it is included in the argumentation: it is the place where the ideology of cleanliness (spiritual and no longer bodily) reveals its oppressive character. At this stage, it becomes necessary to consult Taine's book and replace some of the ideas that were obvious to Norwid at the time with the words of the philosopher of culture:

[...] they [Puritans] have lost the wont of laughter; they fasten inwardly, pale and silent, on their anguish and their expectation; they have but one thought: "Will the Judge pardon me?" [...] The Puritan condemns the stage, the assemblies, the world's pomps and gatherings [...]. The external and natural man is abolished; only the inner and spiritual man survives; there remains of the soul only the ideas of God and conscience - a conscience alarmed and diseased $[\ldots] .{ }^{25}$

24 "Purytanizm" was recently discussed by Jan Zieliński in the article "Stearynowe utrapienie,” [in:] „,Klucze od Echa” - Osobność - Wiersze Cypriana Norwida, ed. E. Kącka, Kraków 2018, pp. 93-102.

${ }^{25}$ H.A. TAINE, History of English Literature, New York 1899, Section V "The Puritans." Online: http://www.gutenberg.org/files/61382/61382-h/61382-h.htm. 
Under the innocent purity of this ideal there hides - the poet concludes - a "cierniowy dyjadem" [thorn diadem] (PWsz II, 68), a crown of martyrdom, which is basically voluntary. Hence the conclusion, Norwid's Ergo: "Że marmur - marmur, zaś mydło jest mydło" [Marble is marble, and soap is soap] (PWsz II, 68). Excessive sacrifice or (as we would say today) provocation are actually psychologically underpinned with pride. The ideal of cleanliness separates believers from the world and its matters, enclosing them within the horizon of their own, eternally vexed conscience, and - which is the worst - elevating them above the imperfect neighbours. This is why the Puritans leaves them to their own fate, which they certainly deserve. He washes his hands of the problem, because "Że - robić z mydła, to - umywać ręce !" [to make from soap is - to wash hands!] (PWsz II, 68). In this sense, the ideal of absolute self-purification is, paradoxically, soapy and brings to mind the ungenerous gesture of Pontius Pilate. Moreover, as a gesture of pride, Puritan sacrifice is internally futile. This is what Taine indicates through his numerous examples, one of which can be quoted here:

One Dr. Leighton was imprisoned fifteen weeks in a dog's kennel, without fire, roof, bed, and in irons: his hair and skin fell off; he was set in the pillory during the November frosts, then whipped, and branded on the forehead; his ears were cut off, his nose slit; he was shut up eight years in the Fleet, and thence cast into the common prison. Many went cheerfully to the stake. Religion with them was a covenant, that is, a treaty made with God, which must be kept in spite of everything, as a written engagement, to the letter, to the last syllable. ${ }^{26}$

However, Taine's conclusion, formulated in the next sentence, is crushing: "An admirable and deplorable stiffness of an over-scrupulous conscience, which made cavillers at the same time with believers, which was to make tyrants after it had made martyrs." ${ }^{27}$ This is why Norwid's poem favours not the inhumanly innocent virgins clad in white satin (as if from a painting by Burne-Jones) but rather the countryside washerwomen, fatigued and muddied to elbows - workers who focus on worldly cleanliness - and dedicates to them the invention of soap.

\section{REFERENCES}

AdAmiec M., 'Tajemnica lorda Singelworth'albo metafizyka balonu, "Studia Norwidiana" 3-4 (1985-1986), pp. 201-215.

${ }^{26}$ Ibid.

${ }^{27}$ Ibid. 
Benjamin W., The Paris of the Second Empire in Baudelaire, [in:] IDEM, The Writer of Modern Life: Essays on Charles Baudelaire, Cambridge, Mass. 2006

Cullerre A., U wrót obłędu. Studyum psychologiczne, trans. L. Wolberg, Warszawa 1891.

David S.-Ch., Philoxène Boyer: Un sale ami de Baudelaire, Paris 1987.

Gomulicki J.W., O 'Trylogii włoskiej' Norwida. Geneza - ksztaltowanie - wymowa, [in:] C. NorwID, Trylogia włoska, ed. J.W. Gomulicki, Warszawa 1979, pp. 5-25.

Prus B., Pisma wszystkie. Humoreski, nowele, opowiadania, vol. 2, ed. T. Żabski, WarszawaLublin 2015.

Rzepczyński S., O umyśle 'zgadobliwym'. 'Tajemnica lorda Singelworth', "Studia Norwidiana" 14 (1996), pp. 105-112.

SAMSEL K., Norwid - Conrad. Epika w perspektywie modernizmu, Warszawa 2015

Skalińska E., Jeszcze o 'Tajemnicy lorda Singelworth'. Między ironia a autoironia, "Colloquia Litteraria" 2017, no. 1, pp. 107-122.

TAIne H.A., History of English Literature, New York 1899, Section V "The Puritans." Online: http://www.gutenberg.org/files/61382/61382-h/61382-h.htm.

Trybuś K., Stary poeta. Studia o Norwidzie, Poznań 2000.

Wilde O., Lord Arthur Savile's Crime and Other Stories, London 1913. Online: https://www. gutenberg.org/files/773/773-h/773-h.htm (accessed 19 January 2021).

Zieliński J., Stearynowe utrapienie, [in:] “Klucze od Echa” - Osobność - Wiersze Cypriana Norwida, ed. E. Kącka, Kraków 2018, pp. 93-102.

\section{$\mathrm{S} \mathrm{u} \mathrm{m} \mathrm{m} \mathrm{a} \mathrm{r} \mathrm{y}$}

This article regards Norwid's Tajemnica Lorda Singelworth in the context of his anthropology as well as historical and cultural background. The author's notion of "cleanliness," inspired in some measure by the Gospels, is connected to the circumstances of both Norwid himself and the main character of his puzzling novella. This reading revolves around the image of a balloon flight during which the Lord - as it is argued, following hints already present in studies of Norwid - discards a piece of paper with "physiological content." This scene is placed in the context of other literary balloon flights and the eccentricity of Baudelaire's friend Philoxène Boyer. Finally, the article discusses Norwid's law of inversion, which can be applied in the case of Singelworth.

Keywords: cleanliness; anthropology; nineteenth-century Paris; irony; inversion.

Eliza KącKa is assistant professor in the Department of Polish Studies at the University of Warsaw, author of Stanistaw Brzozowski wobec Cypriana Norwida (2012) and Lektura jako spotkanie. Brzozowski - tekst - metoda (2017), as well as prose books Elizje (2017) and po drugiej stronie siebie (2019). She edited an anthology of contemporary poetry Poeci i poetki przekraczaja granice (Katowice 2011) and selections of older poetry (e.g. by Cyprian Norwid: "Klucze od Echa". Osobność. Wiersze, Kraków 2018). Member of the Management Board of the Adam Mickiewicz Literary Society (TLiAM); e-mail: eliza.kacka@gmail.com. 